\title{
Land characterization and soil-site suitability- evaluation of banana growing areas of South Gujarat, India
}

\author{
Rajkishore Kumar ${ }^{1}$, J. M. Patel $^{2}$, S. L. Pawar ${ }^{2}$, Narendra singh ${ }^{1}$ and R. G. Patil ${ }^{2} *$ \\ ${ }^{1}$ Soil Science and Agricultural Chemistry, N.M.C.A., Navsari Agricultural University, Navsari-396450 (Gujarat), \\ INDIA \\ ${ }^{2}$ Soil and Water management research unit, Navsari Agricultural University, Navsari-396450 (Gujarat), INDIA \\ *Corresponding author. E-mail: kishorerj1333@gmail.com
}

Received: September 20, 2016; Revised received: April 28, 2017; Accepted: September 12, 2017

\begin{abstract}
An investigation was carried out to evaluate the soil-site suitability and land characterization in some banana growing soils of South Gujarat. The soil belongs to Vertisols, Inceptisols and Enitisols soil order. Banana growing soil (Pedon-1) of Narmada district have ochric epipedon whereas, pedon 2, 3, 4,5, 6 and 9 are placed in order Inceptisols owing to ochric epipedon followed by cambic horizon (changes in colour, structure and texture). The presence of smectite mineralogy class, hyperthermic soil moisture regime and more than 30 per cent clay (but less than 60 per cent), pedon 7 and 8 classified as Inceptisols. In respect of land characteristics, The cumulative rating index of Jhagadia (PN2), Bardoli (PN5) and Palsana (P6) coming under highly sustainable (S2). Whereas, rest of the pedon i.e., Narmada (P1), Bharuch (PN3), Kamrej (PN4) Navsari (PN7), Jalalpore (PN8) and Valsad (PN9) are sustainable under high input (S3). Considering the soil-site suitability criteria, Bharuch (PN3), Palsana (PN6) and Jalalpore (PN8) are identified as highly suitable talukas for banana cultivation. While the Narmada (PN1), Jhagadia (PN2), Kamrej (PN4), Bardoli (PN5), Navsari (PN7) and Valsad (PN9) were categorized in moderately suitable class (S2). The suitability class can be improved if the correctable limitations (soil fertility characteristics) are altered through soil amelioration measures.
\end{abstract}

Keywords: Banana, Land characteristic's, Soil order, Soil -site suitability

\section{INTRODUCTION}

Global issues of the 21 st century like food security, shrinkage of land, demands of food grain production, land and water, climate change and biodiversity are associated with the sustainable use of soils (Lal, 2008, 2009; Jones et al., 2009; Lichtfouse et al., 2009) is now a challenging job to feed the vast population in Asian country and specially for India. Soils have to provide several ecological and social functions (Tóth et al., 2007; Lal, 2008; Jones et al., 2009).

Banana is a global fruit crop with 97.5 million tones of production. Major banana growing areas of the world is geographically situated between the equator and latitudes $20^{\circ} \mathrm{N}$ and $20^{\circ} \mathrm{S}$. India contributes 29.19 per cent of bananas world production. In India it supports livelihood of millions of people with total annual production of 16.91 million tons from 490.7 thousand ha area with national average productivity of $33.5 \mathrm{t} / \mathrm{ha}$ (Anonymous, 2012). In Gujarat, the productivity of banana during 1996-97 was 37.51 t/ha and it increased to $64.09 \mathrm{t} / \mathrm{ha}$ during 2012-13. Application of fertilizer and irrigation through drip system helps to maintain the ideal proportion of soil air and soil water which results in early and vigorous growth of plant. Banana generally grows well in slightly alkaline soils. Banana can be grown well in $\mathrm{pH}$ range of 6.5-7.5. Generally, it favour well drained soil condition with coarse gravel content $(<10)$. Alluvial, volcanic soils and basaltic parent material, are the best for banana cultivation, due to this reason, banana growing soils is hub of banana production in South Gujarat. Basaltic parent material creates the wide heterogeneity towards physical, chemical properties and mineralogical make up under similar pedo- environment (Chetna and Jagdish Prasad 2011). Looking to the inappropriate use of natural resources and consequent decline in productivity at national as well as state levels and more so in coastal ecosystem.

Land quality is the complex attributes of lands and contains one or more land characteristics. Importance of land qualities in any land evaluation includes topography; soil and climate were closely linked to plant requirements (Ritung et al., 2007) for banana crop. The most important land characteristics in land evaluation include drainage, texture, soil depth, nutrient retention ( $\mathrm{pH}$, cation exchange capacity), alkalinity, erosion hazard, and flood/inundation, which limit growth and productivity in banana crop. This factor sometimes considered as an external soil property, preventing soil erosion and providing accessibility by humans and 
machinery (Fischer et al., 2002; Durán Zuazo, 2008). Theses soil qualities are related to the productivity potential and soil site suitability to become more specific for banana crop requirements and tolerances (Fischer et al., 2008). If these characteristics fulfill all requirements, the land characteristics are classified as "highly suitable (S1), "moderately suitable (S2), marginally suitable (S3) and not suitable $(\mathrm{N})$. According to site suitability criteria of banana, optimum growth and yield of banana at a temperature range of $26-30^{\circ} \mathrm{C}$, wind speed should be less than $10 \mathrm{mph}$ but not greater than $25 \mathrm{mph}$ (Naidu et al. 2006). The effective soil depth should be greater than $125 \mathrm{~cm}$ but not less than $50 \mathrm{~cm}$. A suitable banana climate is a mean temperature of $26.67^{\circ} \mathrm{C}$ and mean rainfall of $120-150 \mathrm{~cm}$ annually. There should not be any drier month season for banana cultivation. The information on these aspects for coastal areas for South Gujarat is very scanty for banana crop. The quantitative comparison of some methods need to correlate with physical parameters after standardizing provided similar results (Mueller et $a l ., 2009)$ which were also validate for banana crop. Further locally proven and tested approaches and their indicator sets and thresholds (Wienhold et al., 2004; Zhang et al., 2004; Barrios et al., 2006; Ochola et al., 2006; Govaerts et al., 2006; Sparling et al., 2008) referring to typical banana growing soils in South Gujarat have to be tested on inclusion into the frameworks. Keeping above facts in mind, land resources can be better managed though systematic soil characterization and evaluating their potentials and limitations with appropriate interventions. Hence, present study was planned by land characteristics and evaluating the soil suitability model in typical banana growing soils in South Gujarat.

\section{MATERIALS AND METHODS}

As per climatic classification suggested by Mandal et al. (1999) the district is "semi-arid (dry), small or no seasonal water surplus, hyperthermic, a summer concentric type" and and soil moisture regime is ustic. A three- tier approach (Sehgal et al., 1987) consisting of image interpretation, ground truth collection and laboratory characterization, and cartographic output was made for the survey of the area using base maps consisting of physiographic delineation on 1:50,000 scale (Fig.1). As present study was specially related to banana, it was thought to know the cultural practices being followed for growing banana in selected area of South Gujarat. For this purpose, in all 77 farmers were interviewed personally and the information so obtained is described here (Table 1).For characterization and classification of banana growing area of South Gujarat, five district viz., Narmada, Bharuch, Surat, Navsari and Valsad covering nine taluka viz., Nandod $\left(\mathrm{PN}_{1}\right)$, Jhagadia $\left(\mathrm{PN}_{2}\right)$, Bharuch $\left(\mathrm{PN}_{3}\right)$, kamrej $\left(\mathrm{PN}_{4}\right)$, Bardoli $\left(\mathrm{PN}_{5}\right)$, Palsana $\left(\mathrm{PN}_{6}\right)$, Navsari $\left(\mathrm{PN}_{7}\right)$, Jalalpore $\left(\mathrm{PN}_{8}\right)$, and Valsad $\left(\mathrm{PN}_{9}\right)$ were covered. The climatic parameters viz., rainfall, pan evaporation, relative humidity, temperature, sunshine hours and wind speed, standard weekly wise data for past 20 years (1993-2013) (www.climate.org.in) (Fig.2). The precipitation (P) and Potential evaporation (PE) are generally interpreted simultaneously for drawing sound conclusion related to water balance. From the difference between $\mathrm{P}$ and $\mathrm{PE}$ values it is evident that except Valsad district, all the remaining district are deficit and the maximum deficit is in Bharuch $(-1425 \mathrm{~mm})$ followed by Narmada $(-1302 \mathrm{~mm})$ district. In all the districts, $\mathrm{P}$ is invariably more than PE during July and August month indicating excess moisture condition. In all the districts, the monsoonic months are well defined. The RH values presented in two clear cut group i.e., first group of Bharuch and Narmada district where difference between morning and evening $\mathrm{RH}$ is maximum during May and June months and in second group (Surat, Navsari and Valsad) such difference is experienced from November to April. Among the months, this difference is minimum during all the monsoonic months in all the districts. The monthly average maximum temperature was ranging from $29.5{ }^{\circ} \mathrm{C}$ during January in Valsad district to $40.20{ }^{\circ} \mathrm{C}$ during May in Narmada district. Similarly, the monthly average minimum temperature varied between $12.70{ }^{\circ} \mathrm{C}$ during January in Bharuch and Navsari district and $26.90{ }^{\circ} \mathrm{C}$ during June in Bharuch district. The data further revealed that in all the districts thedifference between minimum and maximum is very less during monsoonic months (June to September and this gap tended to wider on either side of the monsoonic season.As far as sunshine hours is concerned, there are two distinct group i.e., Narmada and Bharuch forming group with maximum sunshine hours observed during May month and in another group comprising Surat, Navsari and Valsad district such condition occurred during April month. Another striking difference between the two groups is in one there is not much variation in sun shine hours before and after May month. However, in group two the mini-

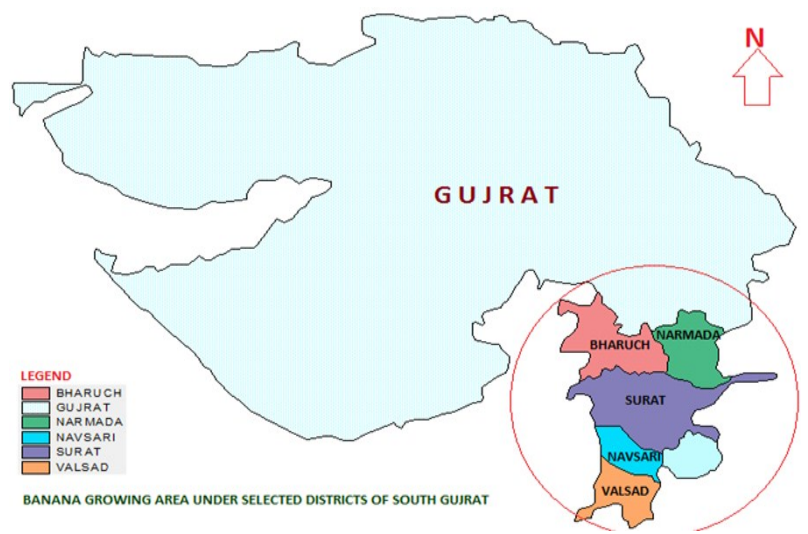

Fig.1. Study area of selected district of banana growing area of South Gujarat. 
mum sunshine hours are recorded during July-August. In general the sunshine hours during July -August in group two is around four hours only. This suggests that the period of cloudy weather is much more in group two in than group one district. With respect to wind speed, it is found to be at its maximum during, June in all the district. The highest wind speed is around 12 $\mathrm{km} \mathrm{hr}^{-1}$ in Narmada and Bharuch district and that in Surat, Navsari and Valsad district it is around $14 \mathrm{~km} \mathrm{hr}^{-1}$. In the entire district during most of the months, wind speed varies between 2 to $4 \mathrm{~km} \mathrm{hr}^{1}$. Wind speed has special significance in judging the climatic suitability of banana, as this crop is prone to lodging during high wind speed.

In all nine profiles i.e., one profile per taluka were excavated and horizon wise samples were collected and studied for morphological characteristics and horizon wise soil samples were collected, air dried, ground and sieved using $2 \mathrm{~mm}$ sieve. Particle size analysis of sample was carried out by using International Pipette Method (Piper 1950). The pH and EC analyzed per the standard procedure by Jackson (1973). Cation exchange capacity (CEC) was determined by leaching the soil with $1 \mathrm{NH}_{4} \mathrm{OAc}$ following the methods of Shollenberger and Simon (1945). The calcium carbonate as per the standard procedure given by Piper (1950) and bulk density by Richard (1954). The soil organic carbon estimated by wet digestion method of Walkey and Black (1934) and the available nitrogen was determined by Subbiah and Asija (1956). The available P in the soil was extracted by employing Olsen et al. (1954) and the available $\mathrm{K}$ was extracted by using Normal ammonium acetate and the content was determined by Aspirating the extract into flame photometer (Jackson 1973). Judge the suitability of banana crop in selected talukas/districts of South Gujarat. For this purpose, two method as described by Lal (1994) and Naidu et al. (2006) have been adopted. The soils were evaluated in different suitability classes viz., S1-suitable, S2moderaltly suitable, S3- marginal suitable, N1currently not suitable and N2-not suitable (Sys et. al. 1991).

\section{RESULTS AND DISCUSSION}

Survey related to banana cultivation: Among the banana growers, 100 per cent farmers use tissue culture plantlets as planting material in all the talukas except Jhagadia (88 per cent) and Chikhli (83 per cent). These suggest that farmers are convinced about the advantages of tissue culture plantlets over suckers. Further, banana growers predominantly prefer Grand Naine variety (92\%). Similarly, on over all basis 88 per cent farmers have adopted drip method of irrigation as against only 12 per cent following flood method of irrigation (Table 1). This seems to be due to wider spacing followed for banana by the farmers. Not only this, but the farmers who have adopted drip meth-

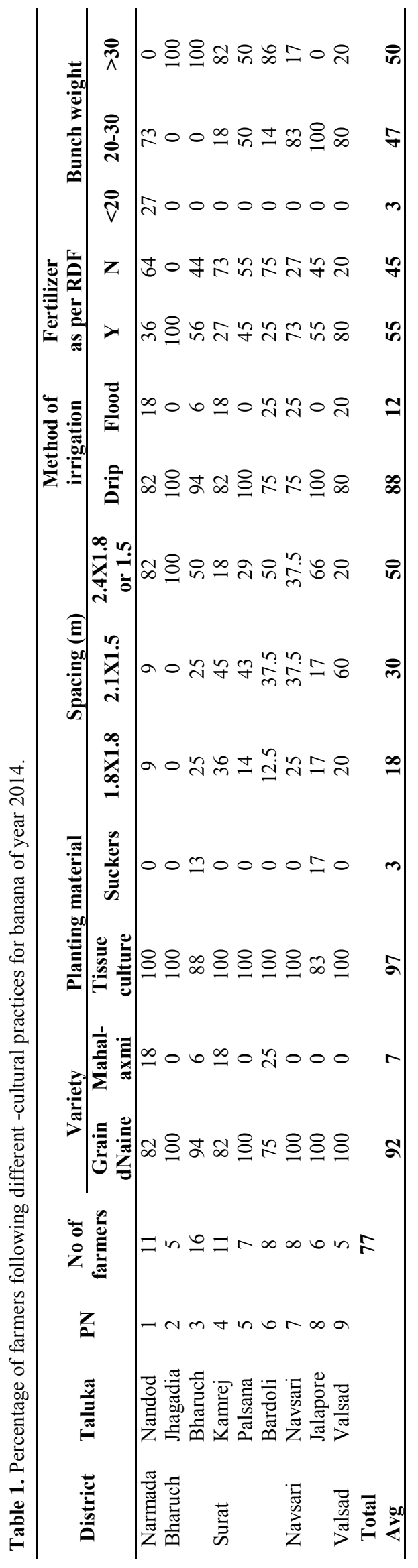




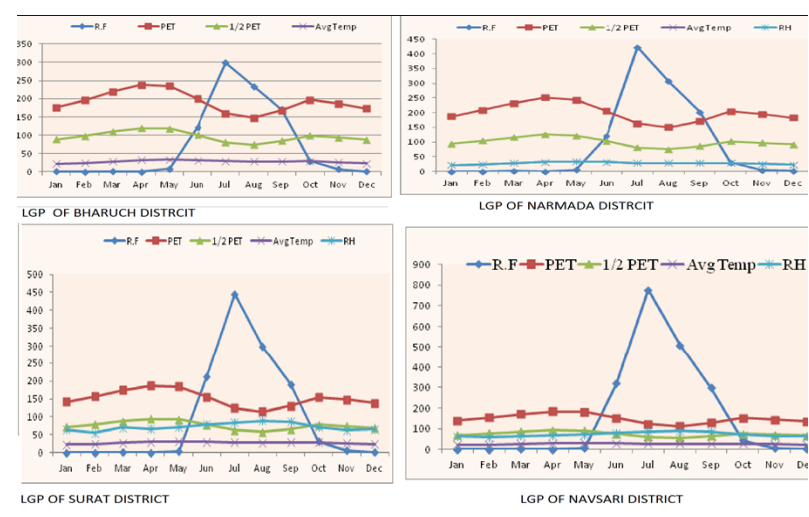

Fig. 2. LGP (Length of growing period) of some selected district of banana growing areas in South Gujarat.

od of irrigation also adopting fertigation practices using predominantly urea for $\mathrm{N}$ and muriate of potash for $\mathrm{K}$. The $\mathrm{P}$ application is done as basal using single superphosphate as source. With respect to rate of fertilizer application, 55 per cent farmers are adopting recommended dose especially for drip irrigated crops. i.e., 60 per cent (300-120-200 g NPK/plant) of recommended dose for flood irrigation banana (180-90-120 g NPK/ plant). The data further revealed that in Bharuch taluka 100 per cent selected farmers are adopting recommended dose of fertilizers and it is followed by Valsad (80\%), Jalalpore (73\%) and Jhagadia (56\%) as well as Chikhli (55\%). With respect to average bunch weight, only in Nandod taluka it was less than $20 \mathrm{~kg}$ average bunch weight. In rest of the talukas, 47 per cent farmers get $20-30 \mathrm{~kg}$ average bunch weight and remaining 50 per cent get more than $30 \mathrm{~kg}$ average bunch weight. If we look at the yield level achieved by the farmers of South Gujarat, it ranges from 40 t/ha in Narmada district to $125 \mathrm{t} /$ ha in Bharuch district. On overall basis, it is evident that banana growers are adopting improved packages of practices like tissue culture, drip irrigation and fertigation, high yielding variety etc., and harvesting excellent yield of banana i.e., up to $125 \mathrm{t} / \mathrm{ha}$ (Table1).

Soil classification: The soil classification is a method to systematic organization the knowledge and perception about the attributes of soils to facilitates the communication and understanding at uniform levels on national and international scenario with an aim to produce a single hierarchical classification which have a pyramid from where the relative few units make up the summit and lower units, increasingly, subdivided and numerous make up the base. Soil classification serves two problems: i) It classifies the higher units to group the major soil types of the world according to genesis of the basic properties and thus provides a framework of some kinds, to act as a basis for the science of pedology; ii) provides a means of making large - scale maps for practical purpose, such as agronomy which often necessitates the use of detailed characteristics that are off local importance only, in defining and naming units. It is obvious that classification of lower units involves entirely different problems from that involves in dealing with the higher units. In order to understand the soils of South Gujarat properly, in all 9 profile were excavated in selected talukas of different districts of South Gujarat. Based on the horizon wise physical and chemical properties of the soils, taxonomic classification was done by adopting the standard procedure as described in revised version of soil taxonomy (Soil Survey Staff, 2010). The soils of the study area predominantly belong to three orders namely Entisols, Inceptisolsand Vertisols (Table 2). The order wise detailed classification is discussed below.

Entisols: Banana growing soil (Pedon-1) of Narmada district have ochric epipedon but due to shallow solum depth of $21 \mathrm{~cm}$, it does not qualify for cambic horizon. Thus, it is justify to be placed under Entisols. At subor-

Table 2. Classification of the soils of South Gujarat under banana cultivation.

\begin{tabular}{|c|c|c|c|c|c|c|}
\hline S.N. & Pedon & Order & Sub- Order & Great Group & Sub- group & Family \\
\hline 1 & Pedon 1 & Entisols & Orthents & Ustotothrents & Typic Ustothrents & $\begin{array}{l}\text { Fine loamy mixed (calc) hyper- } \\
\text { thermic, Typic Ustorthents }\end{array}$ \\
\hline 2 & Pedon 2 & Inceptisols & Ustepts & Haplustepts & Typic Haplustepts & $\begin{array}{l}\text { Fine loamy mixed (calc) hyper- } \\
\text { thermic, Typic Haplustepts }\end{array}$ \\
\hline 3 & Pedon 3 & Inceptisols & Ustepts & Haplustepts & Typic Haplustepts & $\begin{array}{l}\text { Fine loamy mixed (calc) hyper- } \\
\text { thermic, Typic Haplustepts }\end{array}$ \\
\hline 4 & Pedon 4 & Inceptisols & Ustepts & Haplustepts & Typic Haplustepts & $\begin{array}{l}\text { Fine mixed (calc) hyperthermic, } \\
\text { Typic Haplustepts }\end{array}$ \\
\hline 5 & Pedon 5 & Inceptisols & Ustepts & Haplustepts & Fluventic Haplustepts & $\begin{array}{l}\text { Fine mixed (calc) hyperthermic, } \\
\text { Fluventic Haplustepts }\end{array}$ \\
\hline 6 & Pedon 6 & Inceptisols & Ustepts & Haplustepts & Typic Haplustepts & $\begin{array}{l}\text { Fine mixed (calc) hyperthermic, } \\
\text { Typic Haplustepts }\end{array}$ \\
\hline 7 & Pedon 7 & Vertisols & Usterts & Haplusterts & $\begin{array}{l}\text { Typic Haplusterts/ } \\
\text { Sodic Haplusterts }\end{array}$ & $\begin{array}{l}\text { Fine smectitic (calc) hyperther- } \\
\text { mic, Typic Haplustents/Sodic } \\
\text { Haplustents }\end{array}$ \\
\hline 8 & Pedon 8 & Vertisols & Ustepts & Haplusterts & Typic Haplusterts & $\begin{array}{l}\text { Fine smectitic (calc) hyperther- } \\
\text { mic, Typic Haplustents }\end{array}$ \\
\hline 9 & Pedon 9 & Inceptisols & Ustepts & Haplustepts & Typic Haplustepts & $\begin{array}{l}\text { Fine smectite (calc) hyperther- } \\
\text { mic, Typic Haplustepts }\end{array}$ \\
\hline
\end{tabular}


Rajkishore Kumar et al. / J. Appl. \& Nat. Sci. 9 (4): 1962 -1969 (2017)

Table 3. Soil sustainability, indictors and constraints analysis for selected banana growing area of South Gujarat (Lal, 1994).

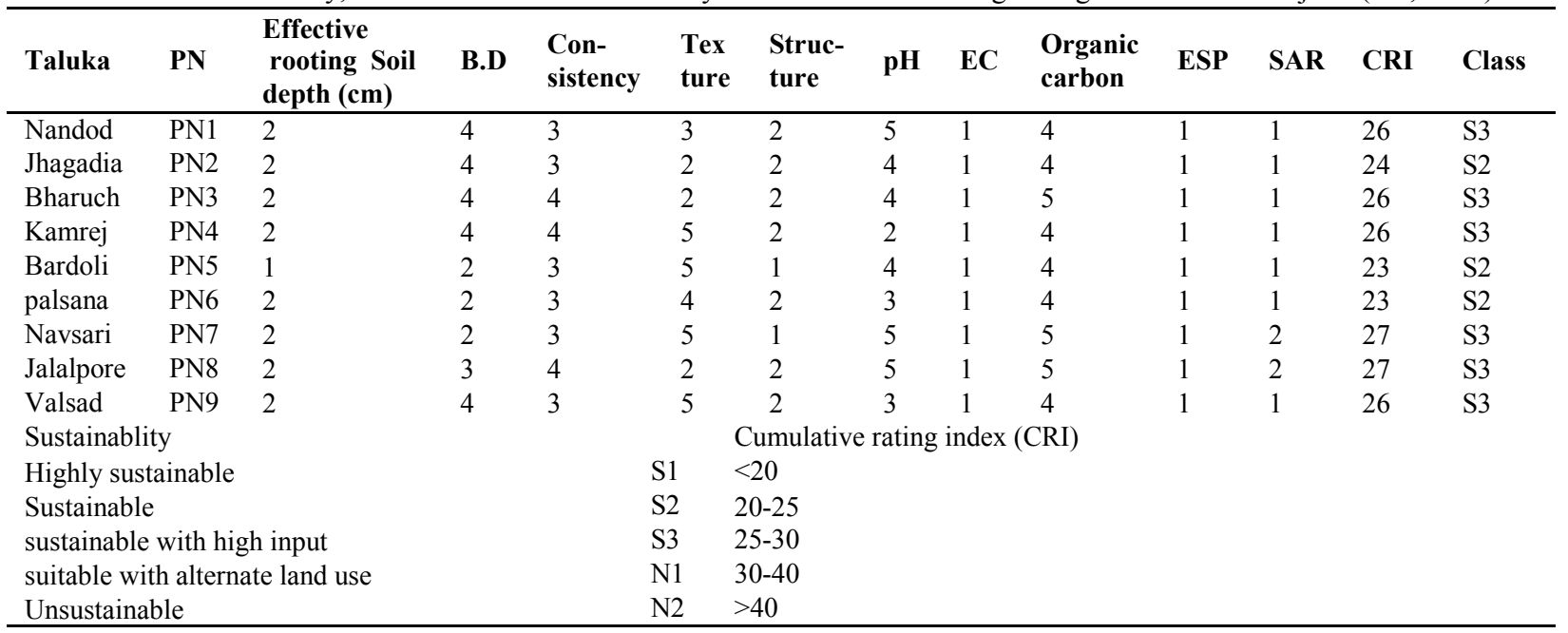

Table 4. Soil site suitability for banana crop (Naidu et al., 2006).

\begin{tabular}{|c|c|c|c|c|c|c|c|c|c|c|c|}
\hline \multirow{3}{*}{ Taluka } & \multirow{3}{*}{$\begin{array}{l}\text { Pro- } \\
\text { file }\end{array}$} & \multicolumn{3}{|c|}{ Climate regime } & \multicolumn{7}{|c|}{ Land characteristics } \\
\hline & & \multirow{2}{*}{$\begin{array}{l}\begin{array}{l}\text { Mean } \\
\text { temp. }\end{array} \\
\left({ }^{\circ} \mathrm{C}\right)\end{array}$} & \multirow{2}{*}{$\begin{array}{l}\text { R.F } \\
(\mathrm{cm})\end{array}$} & \multirow{2}{*}{$\begin{array}{l}\text { No of } \\
\text { mont } \\
h>75 \\
\text { mm }\end{array}$} & \multirow{2}{*}{ Soil Drainage } & \multirow{2}{*}{$\begin{array}{l}\begin{array}{l}\text { Nutrient } \\
\text { availability }\end{array} \\
\text { Texture }\end{array}$} & \multirow{2}{*}{$\begin{array}{l}\begin{array}{l}\text { Rooting } \\
\text { conditions }\end{array} \\
\text { Soil depth }\end{array}$} & \multirow{2}{*}{$\begin{array}{l}\begin{array}{l}\text { Erosion } \\
\text { hazards }\end{array} \\
\text { Slope } \\
\end{array}$} & \multicolumn{3}{|c|}{ Soil toxicity } \\
\hline & & & & & & & & & $\mathbf{p H}$ & $\begin{array}{l}\text { Ece } \\
\left(\mathrm{dSm}^{-1}\right)\end{array}$ & $\begin{array}{l}\text { ESP } \\
(\%)\end{array}$ \\
\hline \multirow{2}{*}{ Nandod } & \multirow{2}{*}{ PN1 } & 27.6 & 91 & 4 & Moderately well & $\mathrm{Cl}$ & 83 & $0-1$ & 8.46 & 0.281 & 2.93 \\
\hline & & $\mathrm{S} 1$ & $\mathrm{~S} 2$ & S3 & $\mathrm{S} 2$ & S1 & $\mathrm{S} 2$ & S1 & $\mathrm{S} 2$ & $\mathrm{~S} 1$ & S1 \\
\hline \multirow{2}{*}{$\begin{array}{l}\text { Jhaga- } \\
\text { dia }\end{array}$} & \multirow{2}{*}{ PN2 } & 27.9 & 72.8 & 4 & Well drain & Sicl & 120 & $0-1$ & 8 & 0.25 & 1.43 \\
\hline & & $\mathrm{S} 1$ & $\mathrm{~S} 2$ & S3 & $\mathrm{S} 2$ & S2 & $\mathrm{S} 1$ & $\mathrm{~S} 1$ & $\mathrm{~S} 2$ & $\mathrm{~S} 1$ & S1 \\
\hline \multirow{2}{*}{ Baruch } & \multirow{2}{*}{ PN3 } & 27.9 & 72.8 & 4 & Well drain & Sicl & 140 & $0-1$ & 7.95 & 0.2 & 2.88 \\
\hline & & $\mathrm{S} 1$ & $\mathrm{~S} 2$ & S2 & S1 & $\mathrm{S} 2$ & S1 & $\mathrm{S} 1$ & $\mathrm{~S} 2$ & $\mathrm{~S} 1$ & S1 \\
\hline \multirow{2}{*}{ Kamrej } & \multirow{2}{*}{ PN4 } & 27.2 & 99.3 & 4 & Moderately well & $\mathrm{c}$ & 115 & $0-1$ & 7.36 & 0.598 & 3.24 \\
\hline & & $\mathrm{S} 1$ & $\mathrm{~S} 1$ & S3 & $\mathrm{S} 2$ & S3 & S1 & $\mathrm{S} 1$ & $\mathrm{~S} 2$ & $\mathrm{~S} 1$ & S1 \\
\hline \multirow[t]{2}{*}{ Bardoli } & \multirow[t]{2}{*}{ PN5 } & 27.2 & 99.3 & 4 & $\begin{array}{l}\text { Somewhat/ } \\
\text { Moderately well }\end{array}$ & $\mathrm{c}$ & 150 & $0-1$ & 8.04 & 0.141 & 1.1 \\
\hline & & $\mathrm{S} 1$ & S1 & S3 & $\mathrm{S} 2$ & S3 & $\mathrm{S} 2$ & S1 & $\mathrm{S} 2$ & S1 & S1 \\
\hline \multirow{2}{*}{ Palsana } & \multirow{2}{*}{ PN6 } & 27.2 & 99.3 & 4 & Moderately well & Sicl & 130 & 1 to 3 & 7.68 & 0.175 & 2.21 \\
\hline & & S1 & S1 & S3 & $\mathrm{S} 2$ & S2 & S2 & S1 & $\mathrm{S} 2$ & $\mathrm{~S} 1$ & S1 \\
\hline \multirow{2}{*}{ Navsari } & \multirow{2}{*}{ PN7 } & 27.4 & 122 & 4 & Moderately well & $\mathrm{c}$ & 105 & 1 to 3 & 8.89 & 0.317 & 9.67 \\
\hline & & $\mathrm{S} 1$ & $\mathrm{~S} 1$ & S3 & S2 & S3 & S1 & $\mathrm{S} 1$ & S2 & $\mathrm{S} 1$ & $\mathrm{~S} 2$ \\
\hline \multirow{2}{*}{$\begin{array}{l}\text { Jalal- } \\
\text { pore }\end{array}$} & \multirow{2}{*}{ PN8 } & 27.4 & 122 & 4 & Moderately well & $\mathrm{cl}$ & 130 & $0-1$ & 8.47 & 0.46 & 6.17 \\
\hline & & $\mathrm{S} 1$ & S1 & S3 & $\mathrm{S} 2$ & S1 & S1 & S1 & $\mathrm{S} 2$ & $\mathrm{~S} 1$ & $\mathrm{~S} 2$ \\
\hline \multirow{2}{*}{ Valsad } & \multirow{2}{*}{ PN9 } & 26.9 & 163.6 & 4 & Moderately well & $\mathrm{c}$ & 110 & 1 to 3 & 7.62 & 0.158 & 2.21 \\
\hline & & S1 & S1 & S3 & S2 & S3 & S1 & $\mathrm{S} 1$ & & $\mathrm{~S} 1$ & $\mathrm{~S} 1$ \\
\hline
\end{tabular}

der levels, it did not qualify for Aquents, Arents, Psamments and Fluents and hence grouped under orthents. Orthents may occur any climate and under any vegeatation. They are not present in areas that have a high water table or on shifting or stabilized sand dunes (Table 2). The surface soil to a depth of $18 \mathrm{~cm}$ is mixed, have less than 30 per cent clay in some subhorizon above a depth of $50 \mathrm{~cm}$, which is qualify under Entisolsto distinguish from Vertisols. It have a lithic or paralithic contact that is shallower than $25 \mathrm{~cm}$ or have a particle - size class that is loamy or finer in some horizon below the Ap horizon or a depth of $25 \mathrm{~cm}$, whichever is deeper, but above a depth of $1 \mathrm{~m}$ or a lithic or paralithic contact, whichever is shallower, or have greater and equal to 35 per cent rock fragments (by volume) in some subsurface horizon within a depth of 1 meter. As it falls under ustic moisture regime, the pedon has been placed under Ustorthents great group. The pedon possessed the central concepts of Typic subgroup levels and hence classified as Typic Ustorthents. The presence of more than 35 percent clay (shallow family), hyperthermic soil temperature regime and mixed mineralogy the pedon is classified as fine loamy mixed, hyperthermicTypic Ustorthents.There was a difference inthe form of surface and subsurface diagnostic horizonsare due to various pedogenetic processes. This is the reasonwhy Entisols (soils formed recently) as a uniform soilorder.

Inceptisols: The soils of pedon 2, 3, 4,5, 6 and 9 are placed in order Inceptisols owing to ochric epipedon followed by cambic horizon (changes in colour, structure and texture). The moisture regime for the region is 
Table 5. Overall soil site suitability for banana crop (Naidu et al., 2006).

\begin{tabular}{|c|c|c|c|c|c|c|c|c|c|c|c|c|}
\hline \multirow{3}{*}{ Taluka } & \multirow{3}{*}{ Profile } & \multicolumn{3}{|c|}{ Climate regime } & \multicolumn{7}{|c|}{ Land characteristics } & \multirow{3}{*}{$\begin{array}{l}\text { Ove } \\
\text { rall }\end{array}$} \\
\hline & & \multirow{2}{*}{$\begin{array}{c}\begin{array}{l}\text { Mean } \\
\text { temp. }\end{array} \\
\left({ }^{\circ} \mathrm{C}\right)\end{array}$} & \multirow{2}{*}{$\frac{\text { R.F }}{(\mathrm{cm})}$} & \multirow{2}{*}{$\begin{array}{c}\text { No of } \\
\text { mont } \\
h>75 \\
\text { mm }\end{array}$} & \multirow{2}{*}{$\begin{array}{l}\text { Soil } \\
\text { Drain- } \\
\text { age }\end{array}$} & \multirow{2}{*}{$\begin{array}{c}\begin{array}{c}\text { Nutrient } \\
\text { availability }\end{array} \\
\text { Texture }\end{array}$} & \multirow{2}{*}{$\begin{array}{c}\begin{array}{c}\text { Rooting } \\
\text { conditions }\end{array} \\
\text { Soil depth }\end{array}$} & \multirow{2}{*}{$\begin{array}{c}\begin{array}{c}\text { Erosion } \\
\text { hazards }\end{array} \\
\text { Slope }\end{array}$} & \multicolumn{3}{|c|}{ Soil toxicity } & \\
\hline & & & & & & & & & pH & ECe & ESP & \\
\hline Nandod & PN1 & $\mathrm{S} 1$ & S2 & S3 & $\mathrm{S} 2$ & S1 & S2 & S1 & S2 & S1 & S1 & S2 \\
\hline Jhagadia & PN2 & S1 & S2 & S3 & S2 & S2 & S1 & S1 & S2 & S1 & S1 & S2 \\
\hline Baruch & PN3 & S1 & S2 & $\mathrm{S} 2$ & S1 & $\mathrm{S} 2$ & S1 & S1 & $\mathrm{S} 2$ & S1 & S1 & S1 \\
\hline Kamrej & PN4 & $\mathrm{S} 1$ & S1 & S3 & $\mathrm{S} 2$ & S3 & S1 & S1 & $\mathrm{S} 2$ & S1 & S1 & $\mathrm{S} 2$ \\
\hline Bardoli & PN5 & S1 & S1 & S3 & $\mathrm{S} 2$ & S3 & S2 & S1 & $\mathrm{S} 2$ & S1 & S1 & $\mathrm{S} 2$ \\
\hline Palsana & PN6 & S1 & S1 & S3 & $\mathrm{S} 2$ & $\mathrm{~S} 2$ & $\mathrm{~S} 2$ & S1 & $\mathrm{S} 2$ & S1 & S1 & S1 \\
\hline Navsari & PN7 & S1 & S1 & S3 & $\mathrm{S} 2$ & S3 & S1 & S1 & $\mathrm{S} 2$ & S1 & $\mathrm{S} 2$ & $\mathrm{~S} 2$ \\
\hline Jalalpore & PN8 & $\mathrm{S} 1$ & S1 & S3 & $\mathrm{S} 2$ & $\mathrm{~S} 1$ & S1 & S1 & $\mathrm{S} 2$ & S1 & $\mathrm{S} 2$ & S1 \\
\hline Valsad & PN9 & S1 & S1 & $\mathrm{S} 3$ & S2 & S3 & S1 & S1 & & S1 & S1 & S2 \\
\hline
\end{tabular}

Ustic so the suborder is ustepts. At great group levels pedon 2, 3, 4, 6 and 9 are classified as Haplustepts but pedon 5 is classifed as fine mixed (Calc) hyperthermic Fluvents Haplustepts at family levels (Table 2).

Vertisols: The soils of pedon 7 and 8 are placed under order vertisols as they haveA layer $25 \mathrm{~cm}$ or thick, with an upper boundary within $100 \mathrm{cmof}$ the mineral soil surface, that has either slickensides or wedge shaped peds that have their long tilted to 10 to $60^{\circ}$ from the horizontal (Table 2). The presence of smectite minerals they have more than 30 per cent clay in all horizon. More than $5 \mathrm{~mm}$ cracks that remain open and close periodically during summer and winter months and remains closed for 1 to 2 during rainy season (Soil Survey Staff, 2010). A group of soils belonging to other soil orders possesses the characteris- tics of black soilsshowing linear extensibility (LE) of $6.0 \mathrm{~cm}$ or more. High (Linear expansion) LE values are caused by smectitic clays that allocatethese soils to vertic sub-group (Soil Survey Staff, 2006). This fact assumes importancebecause Vertisols and the vertic intergrades of soilshave similar characteristics and require similar land managementfor agriculture and allied uses. Presence ofslickensides is not a must for classifying a soil into verticintergrades. Recent studies show that Vertisols and theirintergrades can also possess red colour (Kolhe et al., 2011). Thus the termblack soils for Vertisols and vertic intergrades is technicallywrong. The presence of smectite mineralogy class, hyperthermic soil moisture regime and more than 30 per cent clay (but less than 60 per cent), pedon 7 and 8 classified as fine mixed (Calc) hyperthermic-

Table 6. Constraint based technological interventions banana growing areas in South Gujarat.

\begin{tabular}{|c|c|c|c|}
\hline S. N. & $\begin{array}{l}\text { Constraints for } \\
\text { banana }\end{array}$ & Deleterious effect on root growth & Remedial measures \\
\hline 1. & $\begin{array}{l}\text { High bulk density, } \\
\text { low organic carbon, } \\
\text { hard consistency }\end{array}$ & $\begin{array}{l}\text { Restricted root growth due to difficulty in } \\
\text { penetration of roots }\end{array}$ & $\begin{array}{l}\text { Deep ploughing once in three years } \\
\text { Addition of organic manures like FYM, } \\
\text { biocompost, vermicompost etc. } \\
\text { Green manuring with daincha or sunhemp } \\
\text { Insitu incorporation of crop residue }\end{array}$ \\
\hline 2. & High $\mathrm{pH}$ and ESP & $\begin{array}{l}\text { Stunted growth of plant due to restricted soil } \\
\text { air, moisture and nutrient movement, Apart } \\
\text { from this, extremely high pH }(>9) \text {, Nutrient } \\
\text { availability decreased }\end{array}$ & $\begin{array}{l}\text { Soil analysis based gypsum application in } \\
\text { conjunction with organic manures, green } \\
\text { manuring etc. } \\
\text { Provide drainage facility } \\
\text { Preference to sodicity tolerant variety of } \\
\text { banana }\end{array}$ \\
\hline 3. & $\begin{array}{l}\text { Low in organic car- } \\
\text { bon, Fe and in some } \\
\text { samples } \mathrm{Zn} \text { deficient }\end{array}$ & $\begin{array}{l}\text { Poor plant growth and low yield due to inad- } \\
\text { equate supply of element in question }\end{array}$ & $\begin{array}{l}\text { Apply recommended doses of fertilizer as } \\
\text { per soil test value } \\
\text { Soil test based application of } \mathrm{Fe} \text { and } \mathrm{Zn} \text { with } \\
\text { its } \mathrm{SO}_{4} \text { salt }\end{array}$ \\
\hline 4. & $\begin{array}{l}\text { Marginal or Poor } \\
\text { quality of ground } \\
\text { water }\end{array}$ & $\begin{array}{l}\text { Stunted plant growth and poor yield of plant } \\
\text { Mortality of plant in extreme cases Mortality } \\
\text { extreme cases Deteoriation in soil health due } \\
\text { to prolonged use of such water for irrigation } \\
\text { purpose }\end{array}$ & $\begin{array}{l}\text { Adopt drip irrigation along with mulching } \\
\text { for restricted upward movement of soluble } \\
\text { salts } \\
\text { Follow fertilization schedule using urea and } \\
\text { MOP as source of N and K } \\
\text { Use SSP as a source of P }\end{array}$ \\
\hline 5. & $\begin{array}{l}\text { Low rainfall } \\
\text { (Unmanageable con- } \\
\text { straints) }\end{array}$ & -------- & $\begin{array}{l}\text { Develop drought tolerant variety } \\
\text { Change date of planting in such a way that } \\
\text { full growth stage of plant comes during } \\
\text { monsoon season. }\end{array}$ \\
\hline
\end{tabular}


Typic Haplusterts at family levels because it contain more than 60 per cent clay in control section.

Suitability of banana: Hitherto, judge the suitability of banana crop in selected talukas/districts of South Gujarat. For this purpose, two method as described by Lal (1994) and Naidu et al. (2006) have been adopted ( Table 3). As per Lal (1994) criteria of effective rooting soil depth, except PN5 profile all the other profiles are rated with 2 point i.e., rooting soil depth is less than $150 \mathrm{~cm}$. The occurrence of coarse substratum (Sand loamy sand/ weathered parent material) at a depth of $50 \mathrm{~cm}$ below to clay layer ( $>50 \%$ clay) was identified as the best site for banana cultivation in Wardha district of Maharashtra district (Kadav et. al. 2003).With respect to bulk density, the PN1, 2, 3, 4 and 9 were rated with 4, PN8 with 3 and PN5, 6 and 7 with 2 points as none of the profile sample was having bulk density less than $1.25 \mathrm{~g} / \mathrm{cc}$. From soil consistency point of view, the PN 1, 2, 5, 6, 7 and 9 scored 3 ponits while PN3, 4 and 8 scored 4 points. In the case of texture, PN 4, 5, 7 and 9 scored highest point of 5 followed PN6 with 4 points, PN1 with 3 points and remaining PN2, 3 and 8 with 2 points. The later 3 profile are relatively better suited for banana as compared to the profile with 4 or 5 points. Structurally all the profiles scored 2 point with an exception of PN5 and 7 with 1 point, So structurally, The soils are highly suitable for banana cultivation.Similar evaluation was done earlier by Kharche and Pharandhe (2010). The dominant limitations governing the suitability of most of the crops comprised of soil texture, soil alkalinity drainage and $\mathrm{CaCO}_{3}$. As per the criteria, from $\mathrm{pH}$ point of view, PN1, 7 and 8 scored higher point of 5 followed 4 points with PN2, 3 and 5 and PN6 and PN9 with 3 point and least with PN4 (2). With respect to soil salinity as judged by EC, all the profiles are highly suitable for cultivation of banana as evident from score point of 1. However, in the case of organic carbon content in soil the profiles scored either 4 or 5 point. This suggests that the soils under banana cultivation are deficient in organic carbon. The rating with respect to ESP and SAR clearly suggest that all the profiles scored 1 point except SAR, with PN7 and PN8 having scored 2 points. These parameters are also seems to ideal from banana cultivation point of view. This is agreement with the earlier classification for maize and soyabean by Arunkumar and Sriramchandrasekaran (2013). Based on the cumulative rating index (CRI), PN1, PN 3, PN 7, PN 8 and PN 9 are rated as S3 i.e., sustainable with high input. However, PN2, 5 and 6 profiles are rated as $\mathrm{S} 2$ i.e. in sustainable class (Table 4 and 5).The available information was also used for judging suitability of banana cultivation in different talukas of South Gujarat by following criteria as suggested by Naidu et al. (2006). Considering the climate regime viz., mean temperature, rainfall and number of month receiving $>75 \mathrm{~mm}$ rainfall, the overall class $\mathrm{S} 1$ was designated to PN3 and S2 class for rest of the profile areas. While with respect to land characteristics, the PN 4, 5 and 7 and 9 were grouped in S3 class, PN2 and PN6 in S2 class and the best suited class S1 was allotted to PN1 and PN3. Whereas, in soil toxicity parameters, all soil profile highly suitable for banana cultivation (class S1) except PN7 and PN8. Ultimately, considering climate regime and land characteristics, the profile PN 2, 4, 5, 7 and 9 are classified in class S2 and those of PN1, 3, 6 and 8 classified in S1 class (Table 4 and 5). In general, class of S1 or S2 clearly showing the suitability of soils of the selected talukas of South Gujarat for banana cultivation. Based on rating of both the method of judging the suitability/ sustainability of soils of different talukas of South Gujarat, it is evident that banana cultivation is suitable/ sustainable in South Gujarat. Based on the information related soil-site suitability criteria, production related constraints and technological interventions following conclusion are emerged (Table 6).

\section{Conclusion}

Based on the information related to banana cultivation practices, soil-site suitability criteria, production related constraints and technological interventions following conclusion was emerged. Considering the soil-site suitability criteria, Bharuch (PN3), Palsana (PN6) and Jalalpore (PN8) were identified as highly suitable talukas for banana cultivation. While the Narmada (PN1), Jhagadia (PN2), Kamrej (PN4), Bardoli (PN5), Navsari (PN7) and Valsad (PN9) were categorized in moderately suitable class (S2). The reason may be attribute to the fertility status which can be corrected with land management practices and suitability class upgraded to highly suitable class. The moderately suitable class (S2) for banana cultivation was due to high soil $\mathrm{pH}$ which can be easily amended by application of gypsum to replace sodium on the exchange complex with calcium ions in root zone (rhizosphere soils) and application of organic manures.

\section{REFERENCES}

Anonymous (2012). Directorate of Horticulture, Gujarat state, Gandhinagar

Arunkumar, V. and Sriramchandrasekaran, M.V. (2013). Characterization and evaluation of soils of Lalpur village, Cuddalore district using geospatial technology. Asian Journal of Soil Science 8, 153-156

Barrios E., Delve R.J., Bekunda M., Mowo J., Agunda J., Ramisch J. (2006). Indicators of soil quality: A SouthSouth development of a methodological guide for linking local and technical knowledge, Geoderma 135, 248 $-259$

Chetna and Jagdish Prasad (2011). Chracteristics and Classification of Orange-growing Soils Developed from Different Parent Materials in Nagpur district, Maharashtra, Indian Journal of Soil Sceince, 3, 209-217

Durán Zuazo, V.H., Rodríguez Pleguezuelo C.R. (2008). 
Soil-erosion and runoff prevention by plant covers. $A$ review, Agron. Sustain. Dev. 28, 65-86

Fischer G., van Velthuizen H., Shah M., Nachtergaele F. (2002). Global Agro-ecological Assessment for Agriculture in the 21st Century: Methodology and Results, International Institute for Applied Systems Analysis, Laxenburg, Austria, $154 \mathrm{p}$

Fischer, G.; Nachtergaele, F.; Prieler, S.; Van Velthuizen, H.T.; Verelst, L. and Wiberg, D. (2008). Global Agroecological Zones Assessment for Agriculture, IIASA, Laxenburg, Austria and FAO, Rome, Italy

Govaerts, B., Sayre, K.D. and Deckers, J. (2006). A minimum data set for soil quality assessment of wheat and maize cropping in the highlands of Mexico, Soil Tillage Res. 87, 163-174

Jackson, M. L. (1973). Soil chemical analysis. Prentice Hall of India Private Limited, New Delhi

Jones A., Stolbovoy V., Rusco E., Gentile A.R., Gardi, C., Marechal, B. and Montanarella, L. (2009). Climate change in Europe. 2. Impact on soil. A review, Agron. Sustain. Dev. 29:423-432

Kadav, S.H., Prasad, J. and Gajbhiye, K.S. (2003). Characterization and classification of some typical banana growing soils of Wardha district of Maharashtra. Agropedology, 13(2):28-34

Kharche, V.K and Pharnande, A.L. (2010). Land Degradation assessment and land evaluation in Mula command of irrigated agroecosytem of Maharashtra. Journal of Indian society of soil science 58, 221-227

Kolhe, A. H., Chandran, P., Ray, S. K., Bhattacharyya, T., Pal, D. K. and Sarkar, D. (2011). Genesis of associated red and black shrink- swell soils of Maharashtra. Clay Res., 30, 1-11

Lal R. (2008). Soils and sustainable agriculture. A review, Agron. Sustain. Dev. 28, 57-64

Lal R. (2009). Soils and food sufficiency, A review, Agron. Sustain. Dev. 29, 113-133

Lal, R. (1994). Methods and guidelines for assessing sustainability use of soil and water resources in the topics. Scientific Publishers, Jodhpur. pp. 290

Lichtfouse E., Navarrete M., Debaeke P., Souchère V., Alberola C. (2009). Sustainable Agriculture, Springer, 1st ed., 645 p., ISBN: 978-90- 481-2665-1

Mandal, C., Mandal, D.K., Srinivas,C.V., Sehgal,J. and Velayutham, M (1999) Soil Climatic Database for Crop Palnning in India. NBSS Publ. 53, NBSS\& LUP, Nagpur, India

Mueller L., Kay B.D., Hu C., Li Y., Schindler U., Behrendt A., Shepherd T.G., Ball B.C. (2009). Visual assessment of soil structure: Evaluation of methodologies on sites in Canada, China and Germany: Part I: Comparing visual methods and linking them with soil physical data and grain yield of cereals, Soil Tillage Res.,103:178-87

Naidu, L.G.K., Ramamurthy, V., Challa, O., Hedge, R. and Krishnan, P. (2006). Maunal Soil -Site Suitability Criteria for Major Crops NBSS Publ. No. 129,
NBSS\&LUP, Nagpur, $118 \mathrm{pp}$

Ochola, W.D., Mwonya R., Mwarasomba, L.I. and Wambua M.M. (2006). Farm-level Indicators of Sustainable Agriculture, Classification and description of farm recommendation units for extension impact assessment in Koru, Kenya, in: Häni F.J., Pintér L., Herrens H.R. (Eds.), From Common Principles to Common Practice, Proceedings and outputs of the first Symposium of the International Forum on Assessing Sustainability in Agriculture (INFASA), Bern, Switzerland, pp. 49-76

Olsen, S. R., Core, C. V., Wantage, F. S. and Dean, L. A. (1954). Estimation of available phosphorus in soils by extraction with sodium bicarbonate, PP 1-19. (US Government printing office, Washigton DC)

Piper, C.S. (1950). Soil and Plant Analysis, Academic Press, New York

Richard, L.A. (1954). Diagnosis and improvement of salinealkali soils. Agricultural Handbook, USDA, pp. 60

Ritung, S., Wahyunto, A. F. and Hidayat, H. (2007). Land Suitability Evaluation with a case map of Aceh Barat District. Indonesian Soil Research Institute and World Agroforestry Centre, Bogor, Indonesia

Sehgal, J.L. (1987). Soil site suitability evaluation for cotton. Agropedology, 1: 49-63

Shollenberger, C. J. and Simon, R. H. (1945). Determination of exchange capacity and exchangeable basis in soils: Ammonium acetate method. Soil Science, 59:13-24

Soil Survey Staff (2010). Keys to Soil Taxonomy, USDA, Natural Resource Conservation Service, USDA, Washington DC, 2010, 11th edn

Sparling G., Lilburne L., Vojvodi'c-Vukovi'c M. (2008). Provisional Targets for Soil Quality Indicators in New Zealand, Landcare Research Science Series No. 34, Lincoln, Canterbury, New Zealand

Subbiah, B.V. and Asija, G.L. (1956). A rapid procedure for the estimation of available nitrogen in soil. Curr. Sci., 25:259

Sys C., Van Ranst E. and Debaveye J. (1991): Land Evaluation, Part 1, Principles in Land Evaluation and Crop Production Calculations. International Training Centre for Post- graduate Soil Scientists, University Ghent

Tóth T., Pásztor L., Várallyay G., Tóth G. (2007). Overview of soil information and soil protection policies in Hungary, in: Hengl T., Panagos P., Jones A., Tóth G. (Eds.), Status and prospect of soil information in southeastern europe: soil databases, projects and applications, Institute for Environment and Sustainability, 189:77-86

Walkey, A. and Black, I.A. (1934). An examination of the Determination method for determining soil organic matter, and a proposed modification on the chromic acid titration method. Soil Science 37:29-38

Wienhold B.J., Andrews S.S., Karlen D.L. (2004). Soil quality: a review of the science and experiences in the USA, Environ. Geochem. Health, 26:89-95

Zhang B., Zhang Y., Chen D. and White R.E., Li Y. (2004). A quantitative evaluation system of soil productivity for intensive agriculture in China, Geoderma, 123:319-331 